\title{
Effects of Different Pretreatments to the Seed on Seedling Emergence and Growth of Acacia polyacantha
}

\author{
Edward Missanjo, ${ }^{1}$ Alfred Chioza, ${ }^{2}$ and Chikondi Kulapani' ${ }^{1}$ \\ ${ }^{1}$ Malawi College of Forestry and Wildlife, Private Bag 6, Dedza, Malawi \\ ${ }^{2}$ Department of Agro-Environmental Sciences, Faculty of Agriculture, Kyushu University, 6-10-1 Hakozaki, Higashi-ku, \\ Fukuoka 812-8581, Japan
}

Correspondence should be addressed to Edward Missanjo; edward.em2@gmail.com

Received 27 February 2014; Accepted 22 July 2014; Published 6 August 2014

Academic Editor: Kihachiro Kikuzawa

Copyright (c) 2014 Edward Missanjo et al. This is an open access article distributed under the Creative Commons Attribution License, which permits unrestricted use, distribution, and reproduction in any medium, provided the original work is properly cited.

\begin{abstract}
Acacia polyacantha Willd. is a multipurpose tree species prioritised as one of the agroforestry tree species in Malawi. However, its use in agroforestry practices is limited by the low seedling growth and survival at the nursery stage. A study was conducted to evaluate the seedling growth and survival of Acacia polyacantha as affected by different pretreatments on the seeds at Malawi College of Forestry and Wildlife nursery, Malawi. Seeds were subjected to five presowing seed treatments methods, namely, immersion in cold water at room temperature for 24 hours, immersion in hot water $\left(100^{\circ} \mathrm{C}\right)$ for 5 minutes, immersion in concentrated sulfuric acid $\left(0.3 \mathrm{M} \mathrm{H}_{2} \mathrm{SO}_{4}\right)$ for 20 minutes, scarification by mechanically nicking using secateurs, and a control where seeds were sown without any treatment. The results indicate that presowing seed treatments have positive influence on the seedling growth and survival percentage. Nicked seeds exhibited the highest significant $(P<0.001)$ performance for vegetative characteristics of height, root collar diameter, number of leaves, and survival percentage compared to other pretreatments. Therefore, it is suggested to use nicking as a pretreatment method on Acacia polyacantha seeds in order to enhance the speed and the amount of early seedling growth at the nursery stage.
\end{abstract}

\section{Introduction}

Seed germination and early seedling growth phases are considered critical for raising a successful crop as they directly determine the crop stand density and consequently the yield of resultant crop [1]. It is indicated that seed germination, seedling growth, and survival percentage are governed by many intrinsic and extrinsic factors and are species specific $[2,3]$. Numerous trees have been identified as fast growing and are categorized as high biomass yielders, while many of the tree species have seeds which possess hard seed coats that are impermeable to water; thus, they cannot germinate under normal condition [4]. Therefore, studies on factors that affect germination, survival percentage, and seedling growth for a particular tree species are required.

Acacia polyacantha Willd. is an important multipurpose tree species belonging to the family of Fabaceae and subfamily Mimosoideae [4]. Acacia polyacantha is a large, deciduous tree that grows to an average height of $3.5-20 \mathrm{~m}$ and $3-10 \mathrm{~cm}$ diameter at breast height. Its seeds pods are sweetly scented and borne in spikes, which arise from the nodes. The seed pod appears singly or in clusters of up to four. The number of seeds per pod varies from 3 to 10 and is fairly flattened and dark brown when ripe. The species occurs in wooded grasslands, deciduous woodland and bush land, riverine and groundwater forests. It prefers sites with a high groundwater table, indicating eutrophic and fresh soils [5]. The tree has a wide distribution range in the west, east, and central Africa, specifically in countries such as Botswana, Eritrea, Ethiopia, Gambia, India, Kenya, Malawi, Senegal, Sierra Leone, South Africa, Sri Lanka, Sudan, Swaziland, Tanzania, and Zambia [6].

The tree species commonly known as "White-stem thorn" is well distributed in all regions of Malawi and it has been prioritized as one of the agroforestry tree species [5]. This tree species has various functions in terms of industrial 
application, feeds, and traditional folk medicine. The plant species grows very fast, with the ability to fix nitrogen. It also provides excellent firewood, edible gum, and termiteresistant timber. The leaves and pods provide feed for livestock and game animals. Its heartwood chips are used for tanning and dyeing and its ashes are used as a substitute for salt $[5,6]$.

According to Chanyenga [5] and Chidumayo [7] the smell of the tree is useful in repellent against snakes and crocodiles. The tree roots are used as a remedy for snakebite and as an infusion in which to bath children who are restless at night. The roots possess also considerable therapeutic properties and can be made into a tonic beverage. The bark decoction is used for dysentery to cure venereal diseases and gastrointestinal disorders.

In Malawi, Acacia polyacantha occurs in areas with mean annual rainfall ranging between $700 \mathrm{~mm}$ and $1200 \mathrm{~mm}$, mean annual temperature from 18 to $35^{\circ} \mathrm{C}$, and altitude from 40 to $1800 \mathrm{~m}$ above the sea level. The tree is widely distributed country wide predominantly in savanna woodland on deep fresh soils medium textured to clay, well drained, neutral to alkaline, occasionally on stony slopes and compacted hard soils [8].

Due to its multifunction, Acacia polyacantha becomes a threatened species at risk of extinction. Intentional or unintentional practices such as forest clearing for agriculture and illegal felling for production of firewood, charcoal, medicine, poles, and many other products have reduced this tree species to the extent that they no longer can recover through natural regeneration [9]. This calls for a need to preserve plant biodiversity for prosperity and continuity of plant heritage. Domestication of this species and its subsequent integration into the agroforestry sector is a way to reverse the situation. Thus, study on seed pretreatment to increase germination rate, seedling growth, and survival percentage is needed to provide information for mass production of seedlings. Most of the studies done on Acacia polyacantha and other species in Malawi have concentrated on the germination $[5,10]$. Chanyenga [5] and Likoswe et al. [10] reported that nicking and immersion in hot water presowing treatments enhanced seed germination for Acacia polyacantha and Terminalia serica, respectively. There is no information on the effect of pretreatment methods on seedling growth and survival of germinated Acacia polyacantha in the nursery. To fill the knowledge gap, this study was undertaken to investigate the influence of presowing treatments on the growth and survival of Acacia polyacantha seedlings in the nursery.

\section{Materials and Methods}

2.1. Seed Acquisition and Study Site. Acacia polyacantha seed of Sangadzi provenance, Monkey Bay $\left(14^{\circ} 04^{\prime} \mathrm{S}, 34^{\circ} 56^{\prime} \mathrm{E}\right.$, and $500 \mathrm{~m}$ above sea level), was supplied by Forestry Research Institution of Malawi (FRIM) in March 2013. This study was conducted at Malawi College of Forestry and Wildlife (MCFW) nursery $\left(14^{\circ} 19^{\prime} \mathrm{S}, 34^{\circ} 17^{\prime} \mathrm{E}\right.$, and $1591 \mathrm{~m}$ above sea level) which is located in Malawi near the tropical savannah region in Southern Africa. MCFW receives $1200 \mathrm{~mm}$ to $1800 \mathrm{~mm}$ rainfall per annum, with annual temperature ranging from $7^{\circ} \mathrm{C}$ to $25^{\circ} \mathrm{C}$. It is situated about $85 \mathrm{~km}$ south east of Lilongwe the capital.

2.2. Experimental Design and Treatments. There were five treatments in the experiment: T1, immersion in cold water at room temperature for 24 hours; T2, immersion in hot water $\left(100^{\circ} \mathrm{C}\right)$ for 5 minutes; T3, immersion in concentrated sulfuric acid $\left(0.3 \mathrm{M} \mathrm{H}_{2} \mathrm{SO}_{4}\right)$ for 20 minutes; T4, scarification by mechanically nicking using secateurs; $\mathrm{T} 5$, the controlled experiment. The treatments were completely randomised in four replicates. Each treatment had 50 seeds of equal size, weight, and length making a total of 1000 seeds that were used for the whole treatment.

Seeds were sown on 30 March 2013 in $10 \mathrm{~cm}$ black polythene tubes filled with soil collected from natural woodland (Brachystegia stand). The soil from natural woodland was used because it is free from Acacia polyacantha seeds. One seed was sown per tube at a depth of $2 \mathrm{~cm}$, as recommended by Abideen et al. [11]. Regular watering was done as per requirement to maintain adequate moisture necessary for germination and seedling growth.

2.3. Data Collection and Analysis. Germination was recorded daily for 4 weeks until the cease of emerging germinated seeds. The seed was considered germinated by a visible protrusion of split seed coat with the cotyledons, hypocotyls, and epicotyl on the surface of the soil. Daily germination percentages were summed up to obtain cumulative germination for each treatment. After the completion of seed germination experiment, the growth performance of the seedlings was monitored for six months to assess the seed pretreatment effect on growth. All the seedlings were measured for total shoot height, root collar diameter, and number of leaves once a month. Survival of the seedlings was also assessed at the same interval. Total shoot height was measured by using a $30 \mathrm{~cm}$ ruler and collar diameter by using a microcalliper to the nearest $0.01 \mathrm{~mm}$. The measurements were taken just below the cotyledons. The number of seedlings that survived was also counted in each and every treatment unit.

Germination percentage was calculated by dividing the total number of seeds that germinated in each treatment by the number of seeds sown (excluding dead seeds) and multiplied by 100. Survival percentage of seedlings that survived also was calculated based on the seed germinated [12]. Data on germination percentage, seedling height, root collar diameter, number of leaves, and survival percentage were subjected to Kolmogorov-Smirnov D and normal probability plot tests using Statistical Analysis of Systems software version 9.1.3 [13]. This was done in order to check the normality of the data. After that the data was subjected to analysis of variance (ANOVA) using the same software. Differences between treatment means were detected using Fischer's least significant difference (LSD) at the 0.05 level. 
TABLE 1: Summary of different presowing treatments methods effects on germination percentage, shoot height, root collar diameter, number of leaves, and survival percentage with standard errors in parenthesis of Acacia polyacantha at nursery stages.

\begin{tabular}{cccccc}
\hline & Germination $(\%)$ & Height $(\mathrm{cm})$ & Root collar diameter $(\mathrm{mm})$ & Number of leaves & Survival $(\%)$ \\
\hline Treatment & & & & & \\
T1 & $51.5(1.48)^{\mathrm{c}}$ & $13.25(0.53)^{\mathrm{b}}$ & $2.00(0.02)^{\mathrm{b}}$ & $3.97(0.06)^{\mathrm{b}}$ & $53.6(1.41)^{\mathrm{c}}$ \\
T2 & $76.2(2.08)^{\mathrm{b}}$ & $15.04(0.99)^{\mathrm{b}}$ & $2.25(0.03)^{\mathrm{b}}$ & $4.32(0.09)^{\mathrm{b}}$ & $78.8(1.64)^{\mathrm{b}}$ \\
T3 & $74.8(1.96)^{\mathrm{b}}$ & $14.56(0.97)^{\mathrm{b}}$ & $2.11(0.01)^{\mathrm{b}}$ & $4.17(0.07)^{\mathrm{b}}$ & $75.9(1.55)^{\mathrm{b}}$ \\
T4 & $100.0(0.00)^{\mathrm{a}}$ & $18.74(1.01)^{\mathrm{a}}$ & $3.36(0.02)^{\mathrm{a}}$ & $5.23(0.05)^{\mathrm{a}}$ & $97.4(1.86)^{\mathrm{a}}$ \\
T5 & $42.4(2.36)^{\mathrm{c}}$ & $12.93(0.68)^{\mathrm{b}}$ & $1.99(0.02)^{\mathrm{b}}$ & $3.95(0.08)^{\mathrm{b}}$ & $44.3(2.08)^{\mathrm{c}}$ \\
LSD & 9.1 & 0.27 & 0.14 & 0.09 & 6.1 \\
CV\% & 6.2 & 6.5 & 5.9 & 6.3 \\
\hline
\end{tabular}

Note: means with different subscript within a column significantly differ $(P<0.001)$.

$\mathrm{T} 1$ : immersion in cold water at room temperature for 24 hours, T2: immersion in hot water $\left(100^{\circ} \mathrm{C}\right)$ for 5 minutes, T3: immersion in concentrated sulfuric acid $\left(0.3 \mathrm{M} \mathrm{H}_{2} \mathrm{SO}_{4}\right)$ for 20 minutes, T4: scarification by mechanically nicking using secateurs, and T5: control.

\section{Results}

Summary results for germination percentage, height, root collar diameter, number of leaves growths, and survival percentage of Acacia polyacantha at nursery stage are presented in Table 1 . The results indicate that there was a significant $(P<0.001)$ difference between nicking and the other pretreatments methods for all the parameters studied with nicking producing the highest value. Immersion in hot water was the second most effective method to enhance germination and growth of seedlings. There were no significant $(P>0.05)$ differences between immersion in hot water and immersion in sulfuric acid and between immersion in cold water and control, respectively, for all the parameters studied. However, immersion in water was more superior to immersion in sulfuric acid while immersion in cold water was more superior to the control.

When germination was observed over time, nicking had the highest rate of germination starting from week one. Hot water treatments increased the rate of germination rapidly between the first and second week after which it remained constant. The control had the lowest rate of germination (Figure 1).

The height, root collar diameter, and number of leaves growths of Acacia polyacantha for the period of six months for different pretreatments methods are presented in Figures 2,3 , and 4 , respectively. The height, root collar diameter, and number of leaves growths of Acacia polyacantha were significantly $(P<0.001)$ higher in nicking followed by immersion in hot water. Nicking gave the highest seedling height growth which increased rapidly between May and July and then increased at the decreasing rate between July and October. Immersion in hot water showed the second height growth which increased at an increasing rate between May and July and then increased at the decreasing rate between July and September and remained stable between September and October. A similar trend was also observed for root collar diameter and number of leaves growths.

\section{Discussion}

The present study indicates that nicking produced the highest performance for all the parameters studied (germination

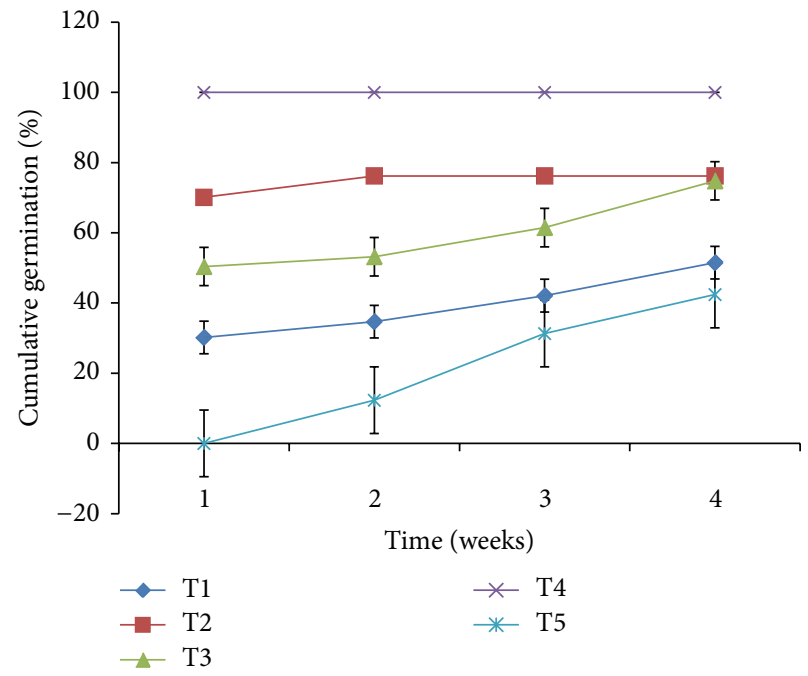

FIGURE 1: Effect of pretreatments methods on the germination of Acacia polyacantha. T1: immersion in cold water at room temperature for 24 hours, $\mathrm{T} 2$ : immersion in hot water $\left(100^{\circ} \mathrm{C}\right)$ for 5 minutes, T3: immersion in concentrated sulfuric acid $\left(0.3 \mathrm{M} \mathrm{H}_{2} \mathrm{SO}_{4}\right)$ for 20 minutes, T4: scarification by mechanically nicking using secateurs, and T5: control.

percentage, seedling height, root collar diameter, number of leaves growths, and survival percentage) compared to the other pretreatment methods followed by the immersion in hot water $\left(100^{\circ} \mathrm{C}\right)$ for 5 minutes. Immersions in concentrated sulfuric acid $\left(0.3 \mathrm{M} \mathrm{H}_{2} \mathrm{SO}_{4}\right)$ for 20 minutes come third while immersion in cold water at room temperature for 24 hours was fourth. The least among the pretreatment methods was the control. High germination, seedling growth, and survival for seeds that were nicked suggest that this is the best method to be applied before planting seeds of Acacia polyacantha. According to Azad et al. [14, 15] and Mwase and Mvula [16], nicking is known to break physical dormancy of seeds with hard coats which inhibit water uptake and gaseous exchange. The results are in agreement with those reported by $[5,10,16$, 17]. Earlier germination of nicked seeds (Figure 1) is a result of cracks or cuts made on the seed which makes it easier for 


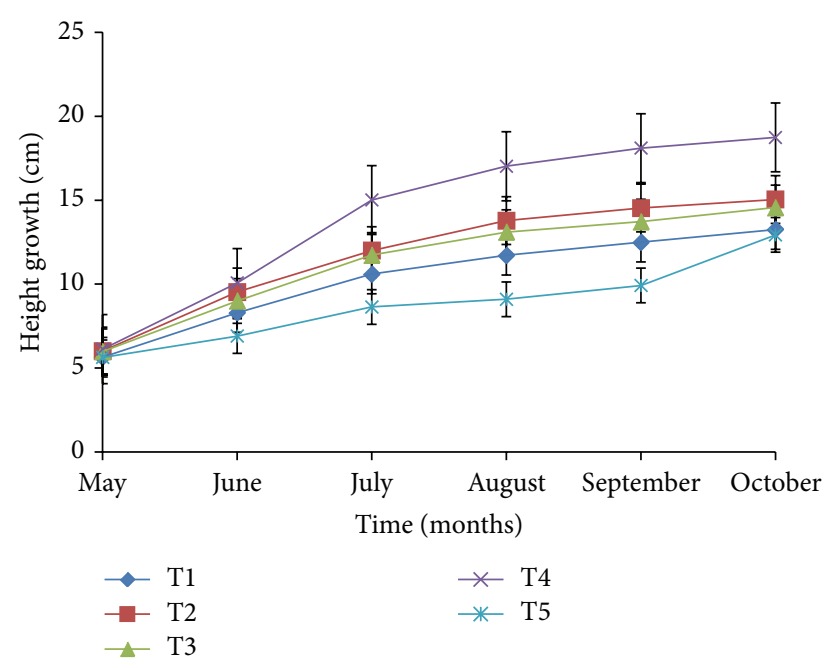

FIGURE 2: Effect of pretreatments methods on the growth height of Acacia polyacantha seedlings. T1: immersion in cold water at room temperature for 24 hours, T2: immersion in hot water $\left(100^{\circ} \mathrm{C}\right)$ for 5 minutes, T3: immersion in concentrated sulfuric acid $(0.3 \mathrm{M}$ $\mathrm{H}_{2} \mathrm{SO}_{4}$ ) for 20 minutes, T4: scarification by mechanically nicking using secateurs, and T5: control.

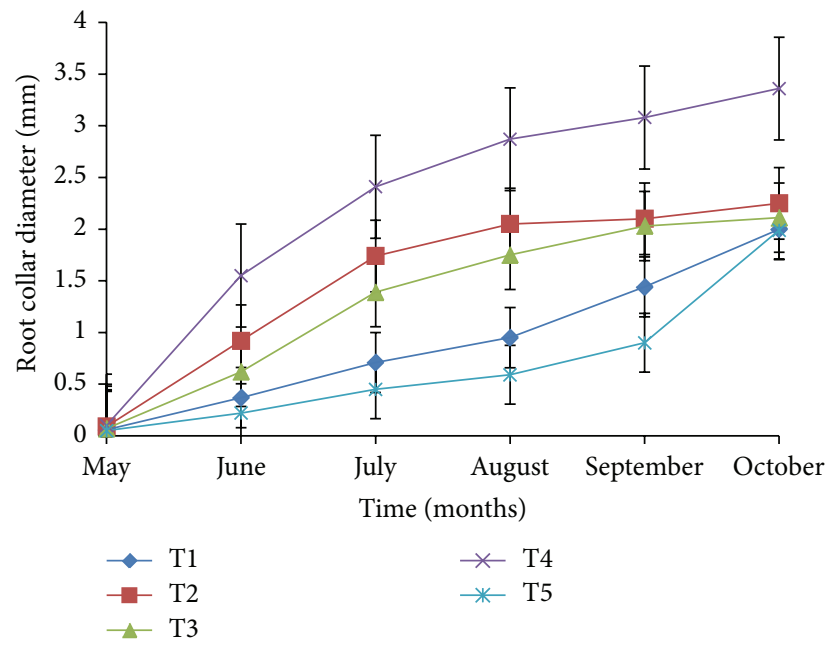

Figure 3: Effect of pretreatments methods on the root collar diameter growth of Acacia polyacantha seedlings. T1: immersion in cold water at room temperature for 24 hours, T2: immersion in hot water $\left(100^{\circ} \mathrm{C}\right)$ for 5 minutes, T3: immersion in concentrated sulfuric acid $\left(0.3 \mathrm{M} \mathrm{H}_{2} \mathrm{SO}_{4}\right)$ for 20 minutes, T4: scarification by mechanically nicking using secateurs, and T5: control.

entry of water and exchange of gases resulting in enzymatic hydrolysis and thus transforming the embryo into a seedling $[16,18-20]$.

In case of growth, seedlings from nicked seeds showed better growth than other treatments. Fast growth of seedlings from nicked seeds (Figures 2 to 4 ) occurred because seedlings originated from nicked seeds had an advantage of absorbing much water and started the photosynthesis process much faster than others. The results are in conformity with other

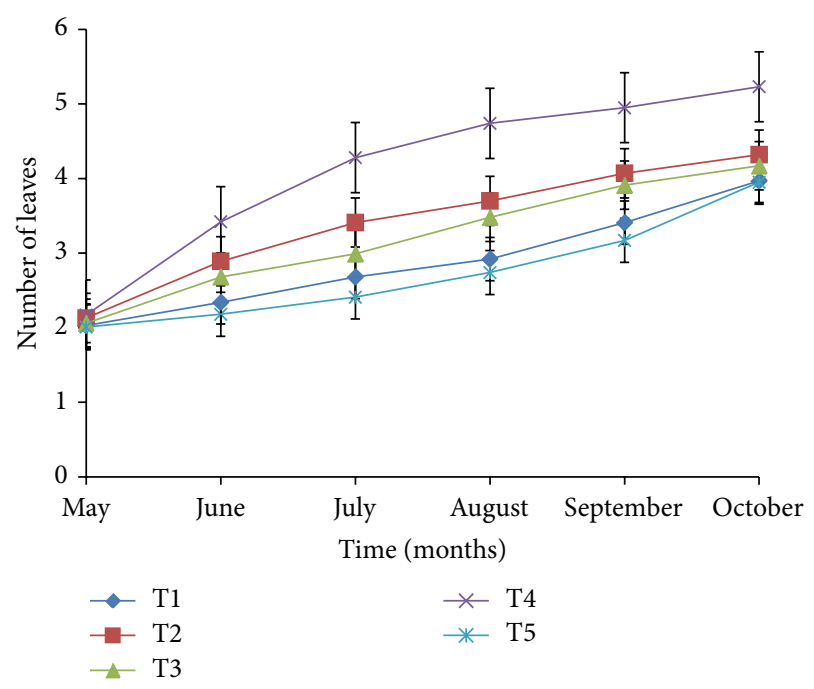

FIGURE 4: Effect of pretreatments methods on the number of leaves growths of Acacia polyacantha seedlings. T1: immersion in cold water at room temperature for 24 hours, T2: immersion in hot water $\left(100^{\circ} \mathrm{C}\right)$ for 5 minutes, T3: immersion in concentrated sulfuric acid $\left(0.3 \mathrm{M} \mathrm{H}_{2} \mathrm{SO}_{4}\right)$ for 20 minutes, T4: scarification by mechanically nicking using secateurs, and T5: control.

researchers [1, 2, 15]. According to Tian et al. [21] seed germination is the most crucial stage that affects earlier seedling growth and establishment.

Seedling mortality in the nursery was largely attributed to the occurrence of shoot dieback (dying back to about $3 \mathrm{~cm}$ below the ground). Low mortality in seedlings developed from nicked seed could be due to its ability to develop a new shoot after dying back by drawing from the large amount of energy reserves contained in the tap root because of its early development and establishment. Munthali [22] reported that there is a positive correlation between shoot dieback and the sizes of the shoot and root in Pterocarpus angolensis seedlings. The present results are in line with [23] which reported that survival of a Pterocarpus angolensis seedling is dependent on the amount of the reserves at the time of regrowth, such that those with greater amount of food reserves were able to regenerate a new shoot.

Hot water treatment was the second best pretreatment seed method for the parameters studied. According to Mwase and Mvula [16] soaking in boiled water makes the seed coats permeable to water the seeds imbibe and swell as the water cools. Most studies reported that immersion in hot water was the best method for breaking the dormancy of hard coat seeds [14, 15, 24, 25]. However, Alamgir and Hossain [19] found the highest germination and seedling growth success in nail clipping followed by hot water treatment. The differences may be due to the difference of temperature and the boiling time and also may be due to the variation of seed coat thickness [15].

There was no significant $(P>0.05)$ difference between immersion in hot water treatment and immersion in concentrated sulfuric acid, although immersion in hot water 
produced the highest performance for all the vegetative characteristics studied. The effect of sulfuric acid on promotion of seed germination, seedling growth, and survival at nursery stage might be due to the highly desiccant effect of the acid on the seed coat thereby allowing easier water uptake and oxygen diffusion [18]. The results are in contrast to those obtained by [18, 26-29]. Olatunji et al. [18] reported higher seed germination, seedling growth, and survival in immersion in concentrated sulfuric acid treatment than other treatments for different seed species. The differences may arise due to the concentration of the acid and the time of exposure for the seeds to the acid, since seeds exposed for a long time get damaged easily $[30,31]$.

Immersion in cold water was less effective and there was no significant difference between the treatments of immersion in cold water and the control. The reason behind this is that the outer coat of the seeds were equally thinned [15].

\section{Conclusion}

The results showed that seedlings raised from nicked seeds had the best germination, vegetative characteristics growth, and survival on the seedlings of Acacia polyacantha. Success of seedlings production depends on the germination capacity from damping off, survivorship, and increase in size. Therefore, using nicking as a pretreatment method of Acacia polyacantha seeds in order to get higher and quicker early seedling growth and survival at nursery stage is suggested.

\section{Conflict of Interests}

The authors declare that there is no conflict of interests in any form regarding the publication of this paper.

\section{Acknowledgment}

The authors thank the staff at Forestry Research Institute of Malawi (FRIM), Seed Section, for providing them with the seeds that were used in this study.

\section{References}

[1] M. A. Hossain, M. K. Aref, B. M. Khan, and M. A. Rahman, "ffects of seed treatments on germination and seedling growth attributes of Horitika (Terminalia chebula Retz.) in the nursery," Research Journal of Agriculture and Biological Sciences, vol. 1, pp. 135-141, 2005.

[2] R. P. Gunaga, D. Doddabasava, and R. Vasudeva, "Influence of seed size on germination and seedling growth in Mammea suriga," Karnataka Journal of Agriculture and Science, vol. 24, pp. 415-416, 2011.

[3] K. S. Murali, "Patterns of seed size, germination and seed viability of tropical tree species in Southern India," Biotropica, vol. 29, no. 3, pp. 271-279, 1997.

[4] R. Dhupper, "Effect of seed pre-treatment on survival percentage of three desert tree species," Journal of Environmental Science, Computer Science and Engineering and Technology, vol. 2, pp. 776-786, 2013.
[5] T. Chanyenga, "Germination of pre-treated Acacia polyacantha (Willd.) seed under nursery conditions at FRIM in Zomba, Malawi," Report No. 06001, Forestry Research Institute of Malawi, Zomba, Malawi, 2006.

[6] M. C. Palgrave, Trees of Southern Africa, Struik, 3rd edition, 2002.

[7] E. N. Chidumayo, "Demographic implications of life history stage characteristics in two African acacias at a Makeni savanna plot in Zambia," Journal of Plant Ecology, vol. 1, pp. 217-225, 2008.

[8] J. S. Pullinger and A. M. Kitchin, Trees of Malawi, Blantyre Print and Publishing, Blantyre, Malawi, 1982.

[9] H. P. Msanga, Seed Germination of Indigenous Trees in Tanzania, UBC Press, Ontario, Canada, 2000.

[10] M. G. Likoswe, J. P. Njoloma, W. F. Mwase, and C. Z. Chilima, "Effect of seed collection times and pretreatment methods on germination of Terminalia sericea Burch.," African Journal of Biotechnology, vol. 7, no. 16, pp. 2840-2846, 2008.

[11] M. Z. Abideen, K. Gopikumar, and V. Jamaludheen, "Effect of Seed Character and its Nutrient content on vigour of Seedlings in Pongamia pinnata and Tamarindas indica," My Forest Journal, vol. 29, pp. 225-230, 1993.

[12] J. D. Maguire, "Speed of germination aid in selection and evaluation for seedling emergency and vigor," Crop Science, vol. 2, pp. 176-177, 1962.

[13] SAS, 9.1.3 Qualification Tools User's Guide, SAS Institute, Cary, NC, USA, 2004.

[14] M. S. Azad, N. K. Paul, and A. Matin, "Do pre-sowing treatments affect seed germination in Albizia richardiana and Lagerstroemia speciosa?" Frontiers of Agriculture in China, vol. 4, no. 2, pp. 181-184, 2010.

[15] M. S. Azad, M. R. Manik, M. S. Hasan, and M. A. Matin, "Effect of different pre-sowing treatments on seed germination percentage and growth performance of Acacia auriculiformis," Journal of Forestry Research, vol. 22, no. 2, pp. 183-188, 2011.

[16] W. F. Mwase and T. Mvula, "Effect of seed size and pre-treatment methods of Bauhinia thonningii Schum. on germination and seedling growth," African Journal of Biotechnology, vol. 10, no. 26, pp. 5143-5148, 2011.

[17] E. Missanjo, C. Maya, D. Kapira, H. Banda, and G. KamangaThole, "Effect of seed size and pretreatment methods on germination of Albizia lebbeck," ISRN Botany, vol. 2013, Article ID 969026, 4 pages, 2013.

[18] D. Olatunji, J. O. Maku, and O. P. Odumefun, “The effect of pretreatments on the germination and early seedlings growth of Acacia auriculiformis Cunn. Ex. Benth," African Journal of Plant Science, vol. 7, pp. 325-330, 2013.

[19] M. Alamgir and M. K. Hossain, "Effect of pre-sowing treatments on germination and initials seedling development of Albizia saman in the nursery," Journal of Forestry Research, vol. 16, pp. 200-204, 2005.

[20] B. E. Ayisire, L. A. Akinro, and S. O. Amoo, "Seed germination and in vitro propagation of Piliostigma thonningii-an important medicinal plant," African Journal of Biotechnology, vol. 8, no. 3, pp. 401-404, 2009.

[21] Y. Tian, B. Guan, D. Zhou, J. Yu, G. Li, and Y. Lou, "Responses of seed germination, seedling growth, and seed yield effect of seed size traits to seed pre-treatment in Maize (Zea mays L.)," The Scientific World Journal, vol. 2014, Article ID 834630, 8 pages, 2014. 
[22] C. Y. R. Munthali, Seed and seedling variation OF pterocarpus angolensis DC from selected natural population of Malawi [Ph.D. thesis], University of Stellenbosch, Stellenbosch, South Africa, 1999.

[23] J. P. Mwitwa, C. R. Y. Munthali, and G. Van Wyk, "Halfsib family variation in shoot and root traits of seedlings of Pterocarpus angolensis (family: Fabaceae; syn. Papilionaceae)," Southern Hemisphere Forestry Journal, vol. 69, no. 2, pp. 91-94, 2007.

[24] M. S. Azad, M. W. Islam, M. A. Matin, and Z. A. Musa, "Effect of pre-sowing treatment on seed germination of Albizia lebbeck (L.) Benth," South Asian Journal of Agriculture, vol. 1, pp. 32-34, 2006.

[25] M. Ali, S. Akhter, and M. Kamaluddin, "Study on the bearing of hot water treatment on seed germination and seedling growth of Albizia procera benth," Indian Forester, vol. 123, no. 8, pp. 764768, 1997.

[26] L. L. El-Juhany, I. M. Aref, and M. A. Al-Ghamdi, "Effects of different pre-treatments on seed germination and early establishment of the seedlings of Juniperus procera trees," World Application Science Journal, vol. 7, pp. 616-624, 2009.

[27] E. Pipinis, E. Milios, P. Smiris, and C. Gioumousidis, "Effect of acid scarification and cold moist stratification on the germination of Cercis siliquastrum L. seeds," Turkish Journal of Agriculture and Forestry, vol. 35, no. 3, pp. 259-264, 2011.

[28] B. Duguma, B. T. Kaiw, and D. U. U. Okali, "Factors affecting germination of Leucaenia leucocephala," Seed Science Technology, vol. 16, pp. 489-500, 1988.

[29] A. M. Aduradola and M. A. Shinkafi, "Aspects of seed treatment for germination in Termarindus indica Linn," ASSET Series A, vol. 33, pp. 29-34, 2003.

[30] M. S. Azad, R. K. Biswas, and M. A. Matin, "Seed germination of Albizia procera (Roxb.) Benth. in Bangladesh: a basis for seed source variation and pre-sowing treatment effect," Forestry Studies in China, vol. 14, no. 2, pp. 124-130, 2012.

[31] L. Schmidt, Guide to Handling of Tropical and Subtropical Forest Seeds, Danida Forest Seed Centre, Humlebaeck, Denmark, 2000 . 

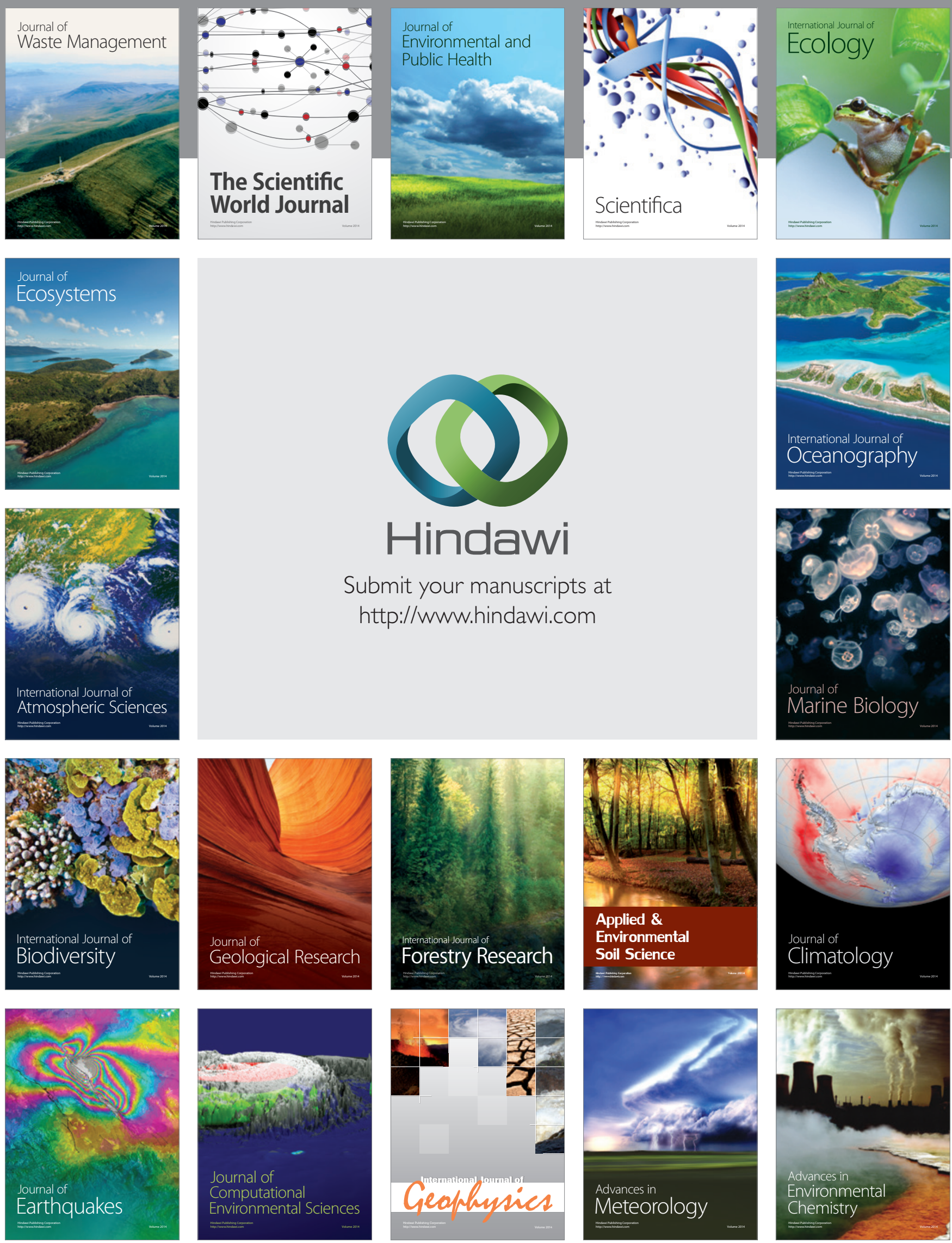